\title{
Hygienic aspects of physical education and health of schoolchildren
}

\author{
Svystun J.D., Trach V.M., Shavel Kh.E., Kukujuk J.M. \\ Lviv State University of Physical Culture, Ukraine
}

\begin{abstract}
Purpose:

to analyze the state of physical education in secondary schools of Ukraine and to observe hygienic requirements during physical education lessons.

Material: $\quad$ the study was attended by schoolchildren ( $n=40$, age $-12-13$ years) and schoolchildren of specialized sports classes ( $n=40$, age - 14-16 years). Studied: the level of physical health; functional state of the respiratory and cardiovascular systems; the state of energy supply of children's organism; the influence of mobile games on the functional capabilities of the body of children. To study the effects of physical exercises on the development of the muscular system of children, excretion of creatinine with urine was studied.

Results: $\quad$ high levels of physical and functional status of young players are noticed. These data are significantly higher than similar data from their peers from non-sports classes. In the course of systematic training and competitions, excretion of creatinine decreases at the end of the season to $0.8 \mathrm{~g} / \mathrm{l}$. These changes point to a decrease in energy resources and are consistent with a decrease in the rapid qualities of young players (as a measure of overall physical fitness). In this group of pupils, there were $2-4 \%$ lessons in the classes: mostly because of colds. In schoolchildren of ordinary schools, indicators of physical development and functional status were significantly worse. The indicators of the lung capacity were $3500-3800 \mathrm{ml}$. The distance of 30 $\mathrm{m}$ children ran for $5,5 \pm 0,4$ seconds. The index of the brush dynamometer was $35 \pm 1,8 \mathrm{~kg}$. The results of the recovery of the heart rate after the metered loading were from 2 to 3 minutes. There is a shortage of body weight in $12 \%$ of schoolchildren. There is an overweight in $1,8 \%$ of schoolchildren.

Conclusions: in the structure of children's morbidity a high level of respiratory diseases, gastrointestinal tract, and eyes is allocated. Therefore, when taking physical training, such data should be taken into account. It is also necessary to take into account the level of individual somatic health, which leads to a safe area of intense motor activity.

Keywords: schoolchildren, life capacity of lungs, dynamometry, Skibinski index, creatinine, phosphorus.
\end{abstract}

\section{Introduction}

The problem of physical education of children and adolescents and its hygienic aspects have practical and scientific significance. Strengthening of health, raising the level of physical fitness of children and adolescents of school age is one of the most acute problems of our state's social policy. Improving the health of schoolchildren in most cases is determined by the level of development of physical qualities, the formation of which takes place in physical education lessons. In recent years, no significant positive changes have taken place in this school in the school system of physical education [2, 3]. Physical culture is a means of upbringing and improving the physical training of schoolchildren. Physical culture is also: the main factor in the restoration and strengthening of health during the formation and formation of the body; a source of general and mental performance improvement [36, 37 , 42]. The state of health of children and adolescents should be considered as a criterion for their readiness to perform labor and social functions $[8,15,30]$.

The physical culture phenomenon by force and ability to influence the preservation and strengthening of human health is one of the most significant $[15,34]$. Therefore, the professional knowledge, functions and activities of the physical education teacher should be aimed at maintaining the health of students.

The study of a number of authors $[8,19,41]$ indicates that the choice of means and regulation of physical activity in physical education and fitness classes should be consistent with somatic health and physical fitness of

(c) Svystun J.D., Trach V.M., Shavel Kh.E., Kukujuk J.M., 2017 doi:10.15561/18189172.2017.0607 schoolchildren. Attempts were made by many domestic and foreign scholars, specialists, managers and individual educators [18, 28, 35]. In school practice, there is a significant deviation from the target settings of physical education and bringing them to purely normative approaches. This worsens the health of schoolchildren and contradicts the idea of forming a harmoniously developed personality [10, 43, 44].

The basis of education and training, a co-ordinating and integrative component of the entire activity of the teacher of physical education at school is a lesson. Features of organization and conducting a lesson in physical culture are determined by the state program. Improving the software for the subject "Physical culture" is one of the main ways to improve the quality of the physical culture lesson. In recent years, many studies have taken into account the hygienic requirements for the process of physical education of schoolchildren. These requirements are based on the physiological laws of the influence of motor activity on the body. Requirements are devoted to the problem of improving the normative and software of physical education of schoolchildren. In the educational process, new curricula for schoolchildren in 1-4 and 5-9 grades are introduced. The organization of the educational process of physical education, taking into account the region of residence, is of great importance. This applies to rural areas where socio-economic and environmental conditions differ from urban living conditions [5, 20, 27, 40].

A special concern for society is the state of health of children. $30-40 \%$ of schoolchildren found nasopharyngeal 
disease; in $20-40 \%$ of breach of posture; in $50 \%$ defects of vision $[14,24,29,48]$. The reasons for the unsatisfactory state of health of schoolchildren of secondary schools and the level of their physical preparedness is the lack of scientifically substantiated system of physical education of schoolchildren [3, 33, 42]. This is due to the fact that the integral concept of this system has not been developed, the ways of its restructuring have not been defined [3]. The modern science of physical education requires the transition from traditional means of gathering information about the physical condition of schoolchildren to comprehensive monitoring. One such information is the creation of an automated system for integrated control of the physical condition of schoolchildren. The purpose of such a system is to identify the differences in physical fitness, individual and personal properties of response to external factors and physical activity [18]. Foreign publications cover the use of new technologies and the creation of a data bank on this basis on the physical condition of the child. Such a base is used for the planning of physical activity, the development of individual programs for independent classes [31, 39, 45, 47].

The social adaptation of the schoolchildren is an important problem. Adaptation is possible only with a high level of health. This requires the creation of a healthsaving educational technology in high school [4, 6, 32, 49]. An important task of the teacher of physical culture is to make active independent motor activity conscious, purposeful. It is necessary to focus on the elements that contribute to: the formation of the need for schoolchildren to improve their health; healthy lifestyle and physical fitness; formation of interest in the use of physical exercises. For the improvement of the educational process at the lessons of physical education, the gender issue is important $[16,38,46]$. In fact, there are no methodical recommendations for teachers, where would be given recommendations on differentiated physical education of boys and girls. We are convinced that in the process of physical education we need to develop a concept of a gender approach aimed at forming a physical culture among schoolchildren. The first step may be to conduct classes individually for boys and girls from the first class. But this innovation requires significant financial costs. Therefore, in today's conditions, taking into account the motivational priorities of girls and boys, it is important to take into account the physical education lesson. This approach makes it possible to select exercises that call and support interest in the lesson [16]. Sanitary and hygienic requirements for the organization of physical education lesson and physical education at school include a number of important provisions: analysis of the results of medical examination; hygiene conditions of the place of the lesson; analysis of the effectiveness of physical education in school according to the incidence of schoolchildren; observance of the sequence of classes and their combination with other lessons in the schedule of the school day and the week [21]. But very often the hygiene requirements for a physical education lesson are not fulfilled, which has negative consequences. In particular, this refers to a combination of the schedule with other lessons (the first lesson of physical culture on Monday).

An important factor in health promotion is to go in for sports in out-of-school period. In senior form about 55\% $-70 \%$ of schoolchildren think so. One of the important reasons may be the impossibility of paying for classes [16]. There is a fairly high percentage of schoolchildren who do not want to go in for sports. It is known that it is the level of individual somatic health that determines the safe zone of intensity of motor activity during exercises.

An aim of the study is to analyze the compliance with hygiene requirements and to generalize the state of physical education in secondary schools of Ukraine, to evaluate the functional condition of schoolchildren in Lviv.

The task of the work is to analyze the functional state and physical preparedness of the schoolchildren under the influence of mobile games: in physical education lessons [26] and in training sessions in Children's and Youth Sports School [22].

\section{Material and methods.}

Participants: schoolchildren of secondary schools № 43 and № 55 ( $n=40$, age - 12-13 years), schoolchildren of specialized sports classes of Children's and Youth Sports School № 4 ( $\mathrm{n}=40$, age - 14-16 years).

Organization of research. We studied: the level of physical health; functional state of the respiratory and cardiovascular systems; the state of energy supply of children's organism; the influence of mobile games on the functional capabilities of the body of children.

Measurement of indicators: height, body weight, Skibinski index, lung capacity, $\mathrm{PWC}_{170}$, maximum of oxygen consumption, anaerobic exchange threshold [23].

To study the effect of physical exercises on the development of the muscular system of children aged 1213 years old, we studied excretion of creatinine in urine. The studies were conducted using a set of reagents for the determination of creatinine in human urine (Filisit Diagnostics, Dnipropetrovsk).

The studies of creatinine were carried out by a colorimetric method by the Jaffe reaction [13].

To detect the rate of inclusion of the creatine phosphokinase mechanism of energy supply when performing physical exercises in children aged 12-13 years, we studied the excretion of inorganic phosphorus with urine.

The purpose of the pedagogical experiment was to determine the effectiveness of our practical recommendations, which were based on the use of mobile games during lesson and out-of-class time. The pedagogical experiment lasted from December 2014 to May 2015. In total we were offered 60 mobile games. Our proposed mobile games are classified: the intensity of the load [games of low intensity - heart rate (heart rate) to 130 beats/min.]; medium intensity - heart rate from 130 to $154 \mathrm{beats} / \mathrm{min}$.); high intensity - heart rate 155 to 174 beats/min.) [17]. In the preparatory part, medium intensity games were used; in the main were used games of high 
and medium intensity (depending on the tasks set); in the final part, were used low intensity games. This approach made it possible to bring the cardiovascular system closer to the baseline level. At each lesson, played 3 to 4 games.

We used mobile games: at physical culture lessons; during big breaks; during morning gymnastics; in extended-day groups; in out-of-class time. In particular: low and medium intensity games were used during the morning gymnastics; low and medium games were used during the big breaks; in middle-aged and high-intensity games in the extended-day groups at out-of-class time.

On the directivity conducted the pedagogical experiment has comparative and consistent aspects. It occurred in a homogeneous group of subjects. According to the aim the experiment was ascertaining and forming. According to the condition of conducting the research, the experiment was natural. Schoolchildren of the control group of the Lviv Secondary School № 43 were engaged in the common methodology.

Statistical analysis: we determined the following indicators: arithmetic mean $-\mathrm{M}$; standard deviation $- \pm \delta$; mean deviation error $- \pm \mathrm{m}$; the validity of the discrepancies according to the Student's t-test. The level of significance was taken at least $p<0,05$.

\section{Results}

At the beginning of the research (Fig. 1-A), in girls, the vital capacity of the lungs was $1720-1754 \mathrm{ml}(\mathrm{p}<0,05)$, in boys $-1795-1850 \mathrm{ml}(\mathrm{p}<0,05)$. These figures are below the age-old norm. In girls at the end of the research (Fig. 1-B) these indicators increased by 51-170 $\mathrm{ml}$. It brought them closer to the age norm. The boys also showed a tendency to increase by an average of $205 \mathrm{ml}$.

The results of the Skibinski index determination at the beginning of the study in boys and girls indicate that the respiratory and cardiovascular function can be assessed as "satisfactorily" (correspondingly 20 and 18 units). At the end of the study, the average values of the Skibinski

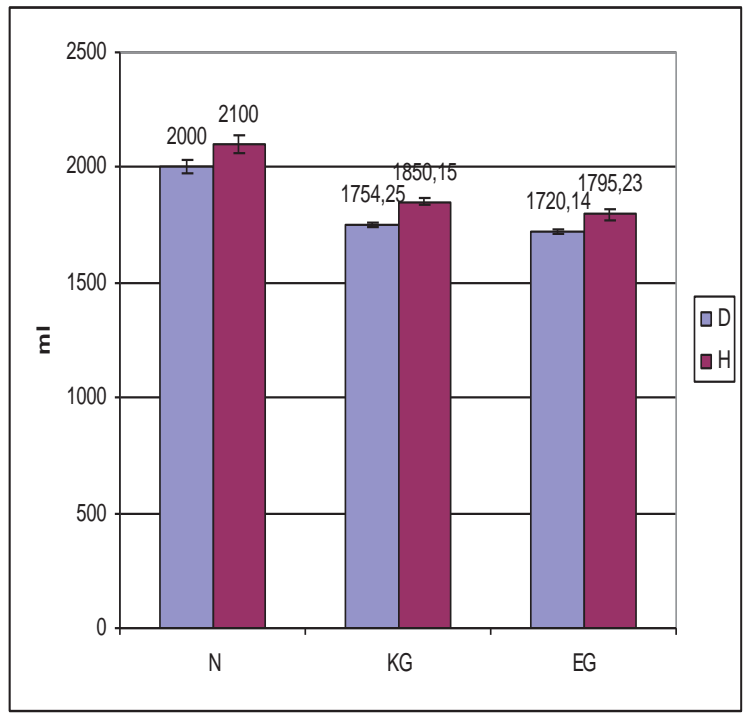

index have a positive tendency for the growth of pupils of both sexes.

The excretion of creatinine with urine in children aged $12-13$ years at the beginning of the study was $0,29-0,0 \mathrm{~g} /$ day ( $41 \%-43 \%$ of the norm). At the end of the study (Fig. 2-A), the following results were obtained: $0,35-0,39 \mathrm{~g} /$ day $(50 \%-56 \%$ of the norm).

After the physical culture lesson, the magnitude of excretion of creatinine at the beginning of the study was $0,34-0,35 \mathrm{~g} /$ day. At the end of the study, the results were 0,42-0,51 g/day (60\%-70\% of norm) (Fig. 2-B).

Excretion of phosphorus with urine at the beginning of the study was $0,64-0,66 \mathrm{~g} /$ day (58\%-60\% of norm) (Fig. $3-\mathrm{A})$. After the physical culture lesson at the beginning of the experiment, the amount of phosphorus was $0,72-0,74$ $\mathrm{g} /$ day (66-67\% of norm) (Fig. 3-B). At the end of the study, the results were $0,75-0,80 \mathrm{~g} /$ day $(68 \%-73 \%$ of norm) (Fig. 3-A, 3-B). Thus, the use of a selection of mobile games points to positive changes in the excretion of creatinine and phosphorus in schoolchildren 12-13 years [17].

Also the indicators of physical development and functional state of schoolchildren in the city of Lviv were studied: the first group - Children's and Youth Sports School (football); the second group - schoolchildren from ordinary non-sport classes. Age of adolescents - 14-16 years. Table 1 shows the physical and functional status of schoolchildren-athletes

From Table 1 data highlights the high physical and functional status of young players. These data are significantly higher than similar data from their peers from non-sports classes. Recovery of heart rate (HR) to baseline values after dosed loading (20 squats for 30 seconds) in this group of schoolchildren was on average 1 min.$1 \mathrm{~min} .30 \mathrm{sec}$. Indicator of general physical fitness in the run of 30 meters was 4,5-4,9 seconds. As an indicator of the intensity of energy metabolism, excretion of creatinine was studied. Determination of creatinine in the urine of the control group of schoolchildren was 1,35 $\mathrm{g} / \mathrm{l}$. In the

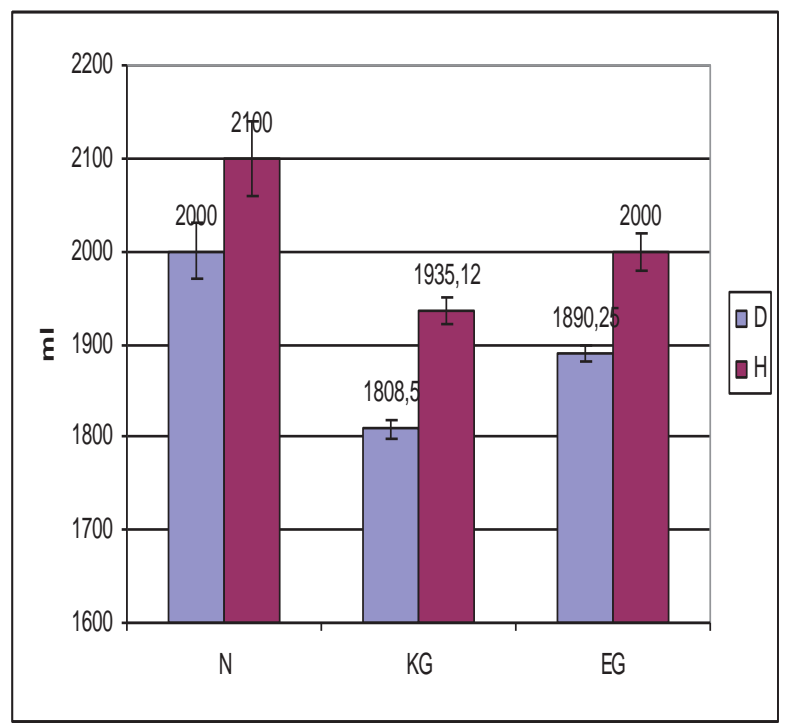

Fig. 1. The magnitude of the vital capacity of the lungs in children aged $12-13$ years at the beginning $(A)$ and at the end (B) of the study $(n=40)$ : $D$ - girls, $\mathrm{H}$ - boys, $\mathrm{N}$ - norm, KG - control group, EG - experimental group, ml - milliliters. 

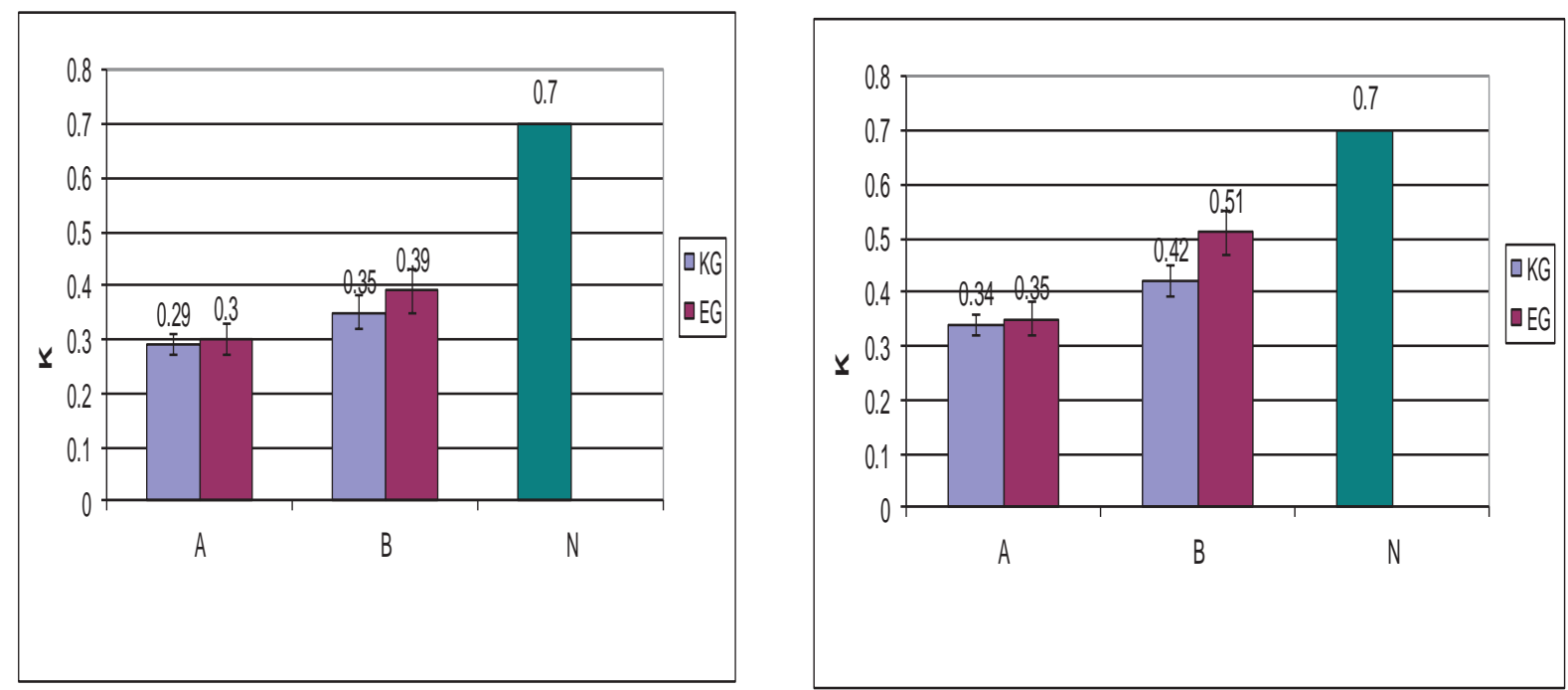

Fig. 2. The magnitude of creatinine excretion ( $F-$ g/day) in children aged 12-13 years in rest $(A)$ and after physical culture lesson (B) $(n=40)$ : $A$ - at the beginning of the study, $B$ - at the end of the study, $N$ - norm, KG - control group, EG - experimental group.
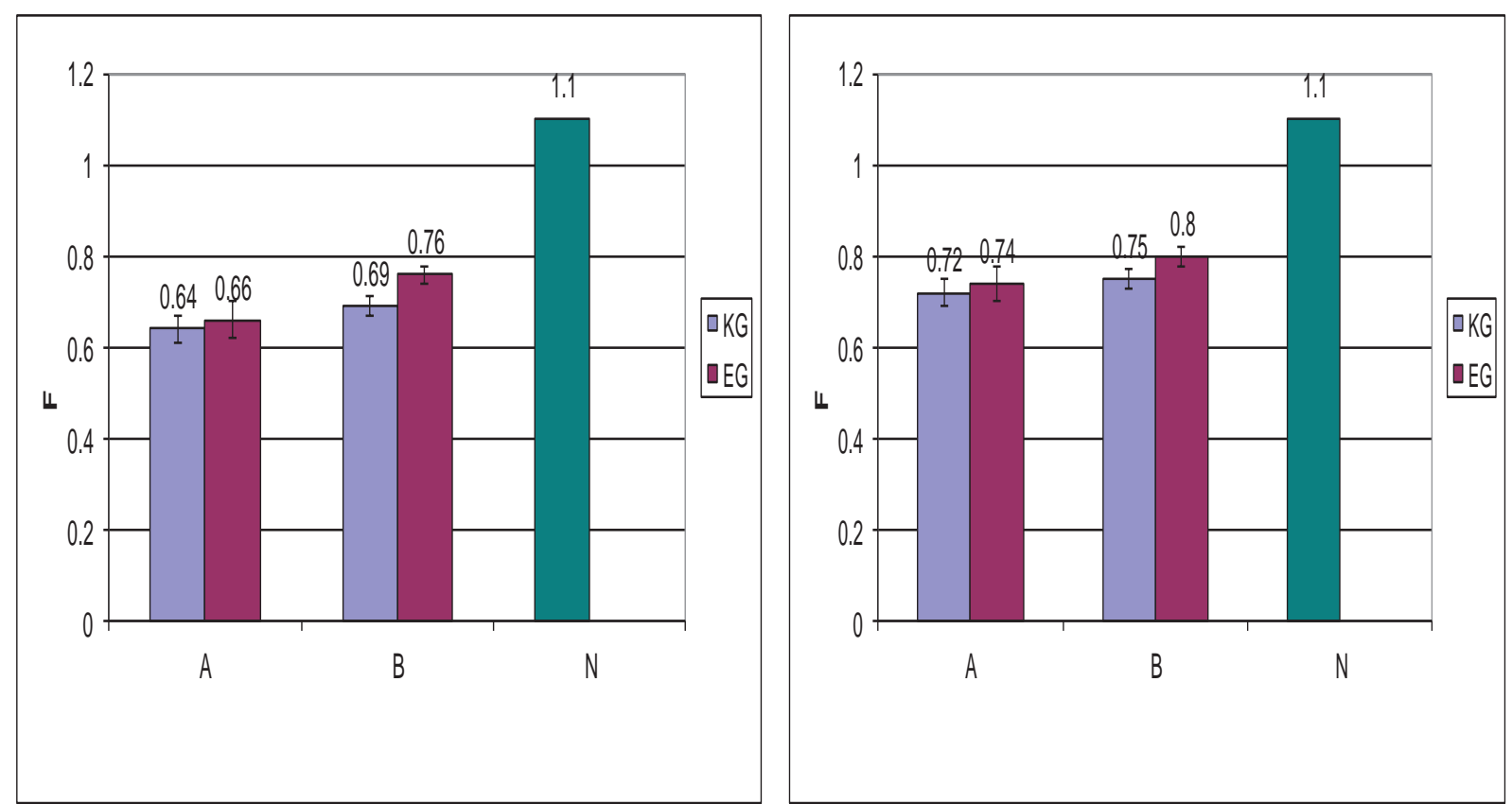

Fig. 3. The magnitude of phosphorus excretion ( $F-g /$ day) in children aged 12-13 years in rest (A) and after physical culture lesson (B) $(n=40)$ : A - at the beginning of the study, B - at the end of the study, N-norm, KG - control group, EG - experimental group.

course of systematic training and competitions, excretion of creatinine decreases at the end of the season to $0,8 \mathrm{~g} / \mathrm{l}$. These changes indicate a decrease in energy resources and are consistent with the decrease in the high-quality qualities of young players (as a measure of overall physical fitness) [19]. In this group of schoolchildren, there were $2 \%$ to $4 \%$ of pupils: mostly because of colds. Such a small number of missing classes by schoolchildren is due to the fact that the trainers of the Children's and Youth Sports School select children according to certain criteria.

In schoolchildren of the ordinary schools, indicators of physical development and functional state were significantly worse. Indicators of vital capacity were $3500-3800 \mathrm{ml}$. The distance of $30 \mathrm{~m}$ children ran for
$5,5 \pm 0,4$ seconds. The index of the brush dynamometer was $35 \pm 1,8 \mathrm{~kg}$. The results of the recovery of heart rate after a dosage loading were from 2 to 3 minutes. In 12\% of schoolchildren, there is a shortage of body weight, and $1,8 \%$ of excess weight.

In the structure of the morbidity of this group is released a high level of diseases of the respiratory system, the gastrointestinal tract, eyes. Missing classes were observed in $22 \%$ of schoolchildren. Therefore, when taking physical training, such data should be taken into account. It is also necessary to take into account the level of individual somatic health, which determines the safe area of intense motor activity and is a criterion for the effectiveness of these activities. 
Table 1. Indicators of physical development and functional state of schoolchildren-athletes of 14-16 years

\begin{tabular}{|c|c|c|c|c|c|}
\hline \multirow{2}{*}{ № } & \multirow{2}{*}{ Type of preparedness } & \multirow{2}{*}{ Control indexes } & \multicolumn{3}{|c|}{ Indexes of preparedness at the age of } \\
\hline & & & 14 years & 15 years & 16 years \\
\hline \multirow{4}{*}{1.} & \multirow{4}{*}{ Physical development } & Body weight (kg) & $55,9 \pm 3,2$ & $55,9 \pm 2,8$ & $65,5 \pm 2,5$ \\
\hline & & Height (cm) & $165,0 \pm 2,3$ & $170, \pm 3,1$ & $176,0 \pm 1,2$ \\
\hline & & Vital capacity (ml) & $3900-4100$ & $4500-4600$ & $4800-5000$ \\
\hline & & Deadlift (kg) & $100-120$ & $120-140$ & $150-160$ \\
\hline \multirow{3}{*}{2.} & \multirow{3}{*}{ Functional state } & $\mathrm{PWC}_{170}(\mathrm{~kg} \mathrm{~m} / \mathrm{min} . / \mathrm{kg})$ & $1400-1600$ & $1600-1850$ & $1800-2000$ \\
\hline & & $\begin{array}{l}\text { Maximum of oxygen } \\
\text { consumption (ml/kg/min.) }\end{array}$ & $50-54$ & $54-56$ & $55-57$ \\
\hline & & $\begin{array}{l}\text { The threshold of anaerobic } \\
\text { exchange (heart rate) }\end{array}$ & $145-155$ & $155-160$ & $160-170$ \\
\hline
\end{tabular}

Note: $\mathrm{PWC}_{170}-$ a test for the determination of physical working capacity, in which the heart rate reaches 170 beats per minute.

\section{Discussion.}

In today's conditions, when conducting a physical culture lesson, motivational priorities are important, which make it possible to select exercises that cause interest in the lesson and increase its effectiveness [10, $16,21]$. Therefore, with the consent of the administration of education in the above mentioned schools, the physical culture lesson was diversified by mobile games, which is a new educational methodical form. This form of the lesson stimulated schoolchildren and during the experiment they showed higher possibilities for the functional state of the body compared with the study of the physical health of schoolchildren in Ukraine by other authors $[8,14]$.

The literature did not address the question of assessing the functional state of schoolchildren according to biochemical indicators during the lessons. This approach made it possible to evaluate the energy capabilities of the organism, to show their changes in the direction of improvement during the school year. Therefore, the results of these studies indicate the ability to recommend mobile games to be included in the school curriculum as a form of exercise in a physical education class.

Studies of most authors show a positive effect in postexercise physical culture and recreational stresses [24]. These studies have established a positive health effect on the functional parameters of the cardiovascular, respiratory and muscular systems. Comparing these data with the indicators of physical development and functional state of schoolchildren trained at the Children's and Youth Sports School, it was clearly established significantly higher functional capabilities of schoolchildren-footballers.

Lampinen E.K. et al studied the differences in physical activity between Finnish girls and boys and children from different socio-economic backgrounds [38]. The authors found that the level of socio-economic preconditions affects the physical activity of children. Tambal K.D. et al highlight the most relevant gender and age differences for the protection of children and adolescents [46]. The authors emphasize that schools should make efforts to improve the level of preparation of schoolchildren through the curriculum of physical culture. These approaches coincide with our results.

Gordon B. et al. presented models for teaching personal and social responsibility of schoolchildren [32]. Zhang T. et al. developed a theoretical model of social and environmental self-realization of schoolchildren in physical activity [49]. The authors note the need for improvement in schoolchildren: physical fitness, development of motor skills, participation in physical life. These results support and coincide with the results of our research.

We were also the first to investigate the excretion of creatinine as a measure of overall physical fitness. The results obtained in such a comprehensive approach to the analysis of physical education classes in schools give grounds to assert that it is necessary to involve schoolchildren not only in extra-curricular physical education and wellness activities, but also in specialized training sessions at the Children's and Youth Sports School.

\section{Conclusions}

1. Studies have established that the improvement of methodical forms of motor activity at the lessons of physical culture improves the indicators of physical development and functional state of schoolchildren.

2. A significant increase in muscle mass and better training of the body of the schoolchildren during systematic sports activities, as evidenced by the excretion of creatinine, has been established.

\section{Conflict of interests}

The author declares that there is no conflict of interests.

The prospect of further research is the study of biochemical parameters, functional state, physical preparedness and health of schoolchildren during systematic physical education classes. 


\section{References}

1. Andrijchuk IuM. Influence of sectional exercises with volleyball on the cardiovascular system and physical performance of schoolchildren. Naukovo-pedagogichni problemi fizichnoi kul turi, 2011;13:9-13. (in Ukrainian)

2. Bulatova MM, Litvin AT. Programs on physical education in secondary education and ways to improve them. Pedagogics, psychology, medical-biological problems of physical training and sports, 2003;19:57-70.

3. Vas'kov IuV. The ways of improving the educational process of physical culture in general educational institutions. Visnik Lugans'kogo nacional'nogo universitetu imeni T.G. Shevchenka, 2010; 17 (204): 103-108. (in Ukrainian)

4. Vashchenko O, Sviridenko S. Readiness of the teacher to use health-saving technologies in the educational process. Zdorov'ia ta fizichna kul 'tura. 2006;8:1-6. (in Ukrainian)

5. Gordijchuk VU. The structure of the free time of rural and urban schoolchildren. Suchasni ozdorovcho-reabilitacijni tekhnologii, 2010;5:126-130. (in Ukrainian)

6. Zhuravleva MS, Setko MP. Socio-hygienic aspects of adolescents' adaptation in modern living conditions. Gigiena i sanitariia, 2009;1:49-51. (in Russian)

7. Kashuba VO, Goncharova NM. Modern approaches to monitoring the physical condition of schoolchildren in the process of physical education. Pedagogics, psychology, medical-biological problems of physical training and sports, 2010;1:71-74.

8. Kostiuk PM, Lapkovs'kij EJ. Assessment of the health status of Ukrainian schoolchildren and factors of its influencing. Fizichna kul'tura, sport ta zdorov'ia nacii, 2011; 1:202-206. (in Ukrainian)

9. Kravchuk IaI. Physical development of primary school students with different levels of educational achievement. Pedagogics, psychology, medical-biological problems of physical training and sports, 2010;3:C. 36-38.

10.Krucevich TIu. The main directions of improvement of programs of physical education of schoolchildren. Teoriia $i$ metodika fizichnogo vikhovannia i sportu, 2006;4:20-27. (in Ukrainian)

11.Krucevich TIu, Bezverkhnia GV. Recreation in the physical culture of different groups of the population. Kiev: Olympic Literature; 2010. (in Ukrainian)

12.Kucher VO, Grigus IM. Application of mobile games and their impact on the body of schoolchildren. Pedagogics, psychology, medical-biological problems of physical training and sports, 2013;1:39-43.

13.Men'shikov VV. Laboratory methods of research in the clinic. Moscow: Medicine; 1987. (in Russian)

14.Lysenko TI, Kazakova TE.The physical health of children of secondary school age. Zdorov'e dlia vsekh, 2012;1:127-130. (in Russian)

15.Liubysheva LI. Sociology of Physical Culture and Sports. Moscow: Academy; 2001. (in Russian)

16. Marchenko OIu. Genderaspects of formation of value potential of students' physical training. Pedagogics, psychology, medical-biological problems of physical training and sports, 2014; 18(11): 38-43. doi:10.15561/18189172.2014.1107

17.Mudrik S. Classification of mobile games by the nature of motor activity. Fizichne vikhovannia, sport $i$ kul'tura zdorov'ia u suchasnomu suspil'stvi, 2002;1:83 - 86. (in Ukrainian)

18. Osipenko EV, Iarchak NL. Pedagogical innovations in physical education as a factor in improving the quality of education. IV scientific and practical conference «Innovative technologies in sports and physical education of the younger generation», May 15-16, 2014, Moscow: MGPU; 2014. P. 40-42. (in Russian)

19.Pal'chuk MB. Preliminary control of indicators of physical development of schoolchildren of the 9th forms as an integral part of the educational process. Fizichna kul'tura, sport ta zdorov'ia nacii, 2011;1:283-288. (in Ukrainian)

20.Pangelova N, Ruban V. Factors that affect the organization of physical education of junior schoolchildren in urban and rural areas. Sportivnij visnik Pridniprov'ia, 2016;1:211-214. (in Ukrainian)

21.Polievskij SA. Physical education of students. Moscow: Medicine; 1989. (in Russian)

22.Svystun YuD, Trach VM, Chornobaj I M, Shavel Kh E. Physical preparedness and functional status of young players in the competition period. Pedagogics, psychology, medicalbiological problems of physical training and sports, 2014; 18(11): 54-60. doi:10.15561/18189172.2014.1110

23.Sergiienko LP. Testing of motor abilities of schoolchildren. Kiev: Olympic Literature; 2001. (in Ukrainian)

24.Sibil' MG, Bodnar UR, Kobrin VM. Physical development and somatic health of pupils of Lviv secondary schools. Visnik Chernigivs'kogo nacional'nogo universitetu imeni T.G. Shevchenka, 2011;1(86): 125-129. (in Ukrainian)

25.Shavel' Kh, Mikhac' T, Svistun Iu. Influence of mobile games on the functionality of the body of children of middle school age. Sportivnij visnik Pridniprov'ia, 2016; 1:230-234. (in Ukrainian)

26. Shiian O. Comparative analysis of the physical condition of middle-aged children studying in rural and urban secondary schools. Sportivnij visnik Pridniprov'ia: 2016;1:235-240. (in Ukrainian)

27.Bliznevsky AA, Kudryavtsev MD, Iermakov SS, Jagiello W. Formation of active-effective attitude of 12-13 years' judo athletes to sports functioning in competition period. Archives of Budo. 2016;12:101-15.

28.Coleman M, Skeen P. Play games and sport. Their use and misure. A development perspective. Childhood Education, 2006;61(3):192-198.

29.Ekberg JE. What knowledge appears as valid in the subject of Physical Education and Health? A study of the subject on three levels in year 9 in Sweden. Physical Education and Sport Pedagogy. 2016;21(3):249-67.

30.Entwistle N. An Ynnovative Strategy to Promote Oral Health in Schoolchildren. The yournal of the Rroyal Society for the Promotion of Health. 1994; 114 (6):311-313. doi:101177/ 146642409411400607

31.Gordon B, Jacobs JM, Wright PM. Social and Emotional Learning Through a Teaching Personal and Social Responsibility Based After-School Program for Disengaged Middle-School Boys. Journal of Teaching in Physical Education. 2016;35(4):358-69.

32.Grad Rafał. Physical activity and leisure time among 13-15-year-old teenagers living in biała podlaska. Physical education of students, 2013; 17(2): 74-79. doi:10.6084/ m9.figshare. 156385

33.Iermakov SS, Podrigalo LV, Jagiello W. Hand-grip strength as an indicator for predicting the success in martial arts athletes. Archives of Budo. 2016;12:179-86.

34.Khudolii OM, Ivashchenko OV, Iermakov SS, Rumba OG. Computer simulation of Junior gymnasts' training process. Science of Gymnastics Journal, 2016;8(3):215-228.

35.Kopeikina EN, Drogomeretsky VV, Kondakov VL, Kovaleva MV, Iermakov SS. Modification of harvard step-test for assessment of students' with health problems functional potentials. Physical Education of Students. 2016;20(4):4450. doi:10.15561/20755279.2016.0405 
36.Kozina ZL, Iermakov SS, Kadutskaya LA, Sobyanin FI, Krzeminski M, Sobko IN, Ryepko OA. Comparative characteristic of correlation between pulse subjective indicators of girl students' and school girls' reaction to physical load. Physical Education of Students. 2016;20(4):2434. doi:10.15561/20755279.2016.0403

37.Lampinen EK, Eloranta AM, Haapala EA, Lindi V, Vaisto J, Lintu N, et al. Physical activity, sedentary behaviour, and socioeconomic status among Finnish girls and boys aged 6-8 years. European Journal of Sport Science. 2017;17(4):46272.

38.Legrain P, Gillet N, Gernigon C, Lafreniere MA. Integration of Information and Communication Technology and Pupils' Motivation in a Physical Education Setting. Journal of Teaching in Physical Education. 2015;34(3):384-401.

39.Molina-Garcia J, Queralt A, Estevan I, Sallis JF. Ecological correlates of Spanish adolescents' physical activity during physical education classes. European Physical Education Review. 2016;22(4):479-89.

40.Moy B, Renshaw I, Davids K. The impact of nonlinear pedagogy on physical education teacher education students' intrinsic motivation. Physical Education and Sport Pedagogy. 2016;21(5):517-38.

41.Pender NV. Motivation for physical activity among children and adolescents. Rev. Nutr.Rds. 1998;16:139-142.

42.Podrigalo LV, Iermakov SS, Avdiievska OG, Rovnaya OA, Demochko HL. Special aspects of Ukrainian schoolchildren's eating behavior. Pedagogics, psychology, medical-biological problems of physical training and sports, 2017; 21(3): 120125. doi:10.15561/18189172.2017.0304

43.Radziminska A，Weber-Rajek M, Lulinska-Kuklik E, Kazmierczak U, Moska W. Academic youth's health behavior. Physical education of students, 2016; 20(6): 55-62. doi:10.15561/20755279.2016.0607

44.Rink Yudith. Teacher perceptions of a physical education statewide assessment program. Rescarch guarterly for exercise and sport, 2007;78(3):204-215.

45.Tambalis KD, Panagiotakos DB, Psarra G, Daskalakis S, Kavouras SA, Geladas N, et al. Physical fitness normative values for 6-18-year-old Greek boys and girls, using the empirical distribution and the lambda, mu, and sigma statistical method. European Journal of Sport Science. 2016;16(6):736-46.

46.Trifonova M. Competency of students in «pre-school and primary school pedagogy» - educational qualification degree bachclor and educational qualification degree master. Trakia yournal of Sciences, 2010;8(3):316-319.

47. Watson A, Eliott J, Mehta K. Perceived barriers and facilitators to participation in physical activity during the school lunch break for girls aged 12-13 years. European Physical Education Review. 2015;21(2):257-71.

48.Zhang T, Thomas K, Weiller K. Predicting Physical Activity in 10-12 Year Old Children: A Social Ecological Approach. Journal of Teaching in Physical Education. 2015;34(3):51736.

Information about the authors:

Svystun J.D.; http://orcid.org/0000-0002-2840-2138; gurin_kristi@ukr.net; Lviv State University of Physical Culture; Kostyushko str. 11, Lviv, 79007, Ukraine.

Trach V.M.; http://orcid.org/0000-0002-8229-2574; gurin_kristi@ukr.net; Lviv State University of Physical Culture; Kostyushko str. 11, Lviv, 79007, Ukraine.

Shavel Kh.E.; http://orcid.org/0000-0002-0153-2549; gurin_kristi@ukr.net; Lviv State University of Physical Culture; Kostyushko str. 11, Lviv, 79007, Ukraine.

Kukujuk J.M.; http://orcid.org/0000-0001-9354-678X; gurin_kristi@ukr.net; Lviv State University of Physical Culture; Kostyushko str. 11, Lviv, 79007, Ukraine.

Cite this article as: Svystun JD, Trach VM, Shavel KhE, Kukujuk JM. Hygienic aspects of physical education and health of schoolchildren. Pedagogics, psychology, medical-biological problems of physical training and sports, 2017;21(6):301-307. doi:10.15561/18189172.2017.0607

The electronic version of this article is the complete one and can be found online at: http://www.sportpedagogy.org.ua/index.php/PPS/issue/archive

This is an Open Access article distributed under the terms of the Creative Commons Attribution License, which permits unrestricted use, distribution, and reproduction in any medium, provided the original work is properly cited (http://creativecommons.org/licenses/by/4.0/deed.en).

Received: 19.05.2017

Accepted: 15.06.2017; Published: 05.11.2017 